\title{
Informação e política nos primórdios da imprensa paulista: O Farol Paulistano (1827-1831)
}

Information and politics in the beginning of the São Paulo press:

The "Farol Paulistano" (Paulistano Lighthouse) (1827-1831)

\section{Carlos Eduardo França de OLIVEIRA}

Resumo: Este artigo tem como objetivo analisar o primeiro periódico impresso na província de São Paulo, O Farol Paulistano (1827-1831), a partir da discussão sobre a estrutura formal do jornal e a atuação política que a folha paulistana exerceu durante o Primeiro Reinado e o início do período regencial, época decisiva para a formação do Estado Nacional brasileiro em moldes liberais.

Palavras-chave: Imprensa; O Farol Paulistano; São Paulo.

Abstract: This article aims to analyze the first newspaper printed in the province of São Paulo, The Farol Paulistano (Paulistano Lighthouse (1827-1831), from the discussion on the formal structure of the newspaper and political action that the paper from São Paulo held during the First Empire and beginning of the Regency period, a decisive period for the formation of the Brazilian National State in liberal molds.

Keywords: Press; The Paulistano Lighthouse; São Paulo.

\section{O surgimento da imprensa em São Paulo: O Farol Paulistano (1827-1831)}

Tendo o Rio de Janeiro como seu ponto de partida (1808), a imprensa no Brasil se alastrou aos poucos pelas demais províncias, como pela Bahia (1811), Pernambuco (1817), Maranhão (1821), Minas Gerais (1823), Ceará (1824), Paraíba (1826) e São Pedro do Rio Grande do Sul (1827) (SODRÉ, 1966; MOREL; BARROS, 2003). ${ }^{1}$ Apesar da importância de São Paulo durante o processo de Independência e consolidação de um regime monárquico-constitucional com sede no Rio de Janeiro no início do século XIX, foi somente em 1827, com o surgimento de $O$ Farol Paulistano, que a imprensa periódica se enraizou em terras paulistas. Antes da publicação do jornal dirigido por José da Costa Carvalho houve algumas tentativas frustradas de se estabelecer um periódico com circulação regular na província, sendo a primeira e mais importante delas resultado da diligência de Antônio Mariano de Azevedo Marques ${ }^{2}$, o Mestrinho, cujo jornal manuscrito $O$ Paulista, lançado em 1823, em poucos meses teve suas atividades encerradas. ${ }^{3}$

O Farol Paulistano veio a público em 7 de fevereiro de 1827, sob a direção de José da Costa Carvalho $^{4}$, e encerrou suas atividades cerca de 4 anos depois, pouco após a eleição do futuro Marquês de Monte Alegre ao cargo de membro da Regência Trina Permanente, em 17 de junho de 1831..$^{5}$ Impresso em tipografia própria intitulada Typographia de Roa \& Cia., posteriormente Tipografia do Farol Paulistano, e situada no $n^{\circ} 33$ da rua S. José ${ }^{6}$, na capital paulista, o Farol era constituído de quatro páginas, esporadicamente seis ou oito, com dimensões de 21 x $31 \mathrm{~cm}^{7}$

\footnotetext{
- Mestre em História - Doutorando - Faculdade de Filosofia, Letras e Ciências Humanas - USP - Univ. de São Paulo Rua do Lago, 717, CEP: 04280-000, São Paulo, SP, Brasil. E-mail: carlosoliveira@ usp.br
} 
Segundo Afonso de Freitas, o primeiro impressor de $O$ Farol foi o espanhol José Maria Roa que, trabalhando com um prelo de madeira, produzia cerca de 25 exemplares por hora, ou seja, 225 exemplares/dia numa jornada de nove horas de trabalho (FREITAS, 1928, p. 20). Apesar da lógica do cálculo, é difícil precisar uma tiragem aproximada da folha, uma vez que em decorrência dos poucos recursos das tipografias na época, os problemas técnicos eram constantes e podiam comprometer a regularidade na impressão dos periódicos. Entre maio e junho de 1829, por exemplo, o Farol ficou cerca de dez dias sem ser publicado por conta da quebra do prelo da Tipografia do Farol Paulistano. ${ }^{8}$ Além da compra avulsa, que podia ser feita junto à tipografia por 80 rs., o jornal também era comercializado mediante assinaturas trimestrais. ${ }^{9}$

Inicialmente o jornal circulava uma vez por semana, passando a ser bissemanal ${ }^{10}$ a partir de junho de 1827 e trissemanal entre outubro de 1829 e seu término. Segundo o próprio Farol, a opção por fazer o jornal ir a público três vezes por semana - às terças, quintas e sábados - foi fruto tanto da melhoria das condições técnicas da tipografia do Farol, mediante a compra de um novo prelo, em junho de 1829, como da importância de serem abarcadas questões até então pouco contempladas pela folha, tais como as oscilações cambiais, o movimento do porto de Santos e os preços de gêneros de exportação e importação da província de São Paulo e do Rio de Janeiro. Ademais, atestava-se a importância de serem transcritos excertos de periódicos oriundos de outras províncias, de modo que a seleção de artigos operada pelo Farol redimiria seus leitores, no entender do redator, de lerem as folhas originais. ${ }^{11}$ Quanto a esse último ponto, mesmo levando em conta o significativo aumento da quantidade de periódicos editados nas diversas regiões do Império, é possível entrever uma estratégia do redator em selecionar, filtrar e publicar artigos dessas folhas que corroborassem ou não com suas ideias, tornando-as assim passíveis de uma instrumentalização discursiva e política.

Similarmente a outras folhas do período, o Farol foi um jornal composto por diversos redatores. Ainda que aparentemente tenha ficado sob a direção de José da Costa Carvalho em todo seu tempo de duração, e que autores como S. A. Sisson creditaram ao futuro Marquês de Monte Alegre a redação de todo o periódico, o mais provável é que o Farol Paulistano tenha sido levado a cabo por diversos redatores em diferentes períodos, tal como sugeriram Afonso de Freitas e, mais recentemente, Arnaldo Contier (SISSON, 1999; FREITAS, 1928; CONTIER, 1979).

As páginas de $O$ Farol não oferecem dados precisos em relação a essas alterações, mas sugerem que as mudanças de redator, mesmo que temporárias, foram constantes ao longo dos quase cinco anos de duração do jornal. A primeira delas, ocorrida no $\mathrm{n}^{\mathrm{o}} 12$, ou seja, pouco após a fundação do jornal, teve como justificativa a ida do redator ao Rio de Janeiro. ${ }^{12}$ Ainda em 1827 , outra substituição foi efetuada, só que dessa vez a explicação residiu no fato de o redator em exercício entre o $\mathrm{n}^{\mathrm{o}} \mathrm{s} 12$ e 38 ter adoecido gravemente. ${ }^{13}$ 
A alternância de redatores possibilitou ao Farol a criação de um instrumento de defesa diante das críticas eventualmente recebidas, já que a inexistência de um único responsável supostamente redimia o periódico de ser cobrado quanto à manutenção de um discurso coerente em seu todo. Não se tratava, naturalmente, de legitimar a publicação de ideias diametralmente opostas - o que de fato nunca ocorreu -, mas de justificar possíveis alterações no discurso geral do periódico. Em abril de 1830, o autor do artigo principal inseriu uma nota de rodapé na qual explicou que as posições defendidas em seu texto, por serem passíveis de controvérsia, não deveriam ser tomadas como vindas do "principal redactor" de $O$ Farol, uma vez que esse se encontrava fora da cidade de São Paulo. ${ }^{14}$ Um ano depois, já nos últimos números da folha, o então redator não discordou de uma correspondência inserta em O Observador Constitucional, também impresso na capital paulista, o qual acusava o Farol de ser escrito por redatores "interinos". ${ }^{15}$ Podendo ser considerado um momento de transformação do teor político-ideológico de o Farol - posto que esse passou a concordar com algumas propostas dos ditos "liberais exaltados", tal como reformar aspectos da Carta de 1824, como se verá mais adiante -, o período pós-Abdicação marcou um re-alinhamento discursivo na folha paulista, de modo que a aceitação desse caráter "interino" figurava menos como o reconhecimento de uma constatação externa e mais como um aval para a mudança no tom do discurso do periódico.

Nesse âmbito, torna-se difícil afirmar com precisão quais foram os redatores de $O$ Farol ao longo de sua publicação. A bibliografia e as fontes sugerem que José da Costa Carvalho e Antonio Mariano de Azevedo Marques tenham sido seus principais redatores, desempenhando essa função de forma descontínua, porém por um período mais longo que os demais. Costa Carvalho, que tomou posse como deputado nas duas primeiras legislaturas do Império, retirava-se da cidade de São Paulo com regularidade, muito provavelmente durante o período de funcionamento da Câmara dos Deputados, entre maio e setembro, fato que pode ser constatado pelas suas ausências ao longo das sessões extraordinárias do Conselho da Presidência da província de São Paulo, que ocorriam concomitantemente às do Legislativo. ${ }^{16}$ Azevedo Marques, todavia, por não ter ocupado cargos públicos fora de São Paulo durante o tempo de funcionamento de $O$ Farol, parece ter permanecido por mais tempo na capital paulista, o que também pode ser observado pela assiduidade nas reuniões do mesmo Conselho da Presidência. ${ }^{17}$ Numa ocasião em que o Farol recebeu um ofício do Palácio do Governo de São Paulo sobre a regularização do funcionamento da Sociedade Filantrópica da capital paulista, o nome de Azevedo Marques apareceu como destinatário do documento a ser publicado, o que sugere uma participação ativa do Mestrinho da elaboração da folha de Costa Carvalho. ${ }^{18}$ Ademais, vale lembrar que Azevedo Marques ocupou a Cadeira de Latim e Retórica anexa ao Curso Jurídico entre 1828 e 1835, função que desempenhou com regularidade (TAUNAY, 1956, p. 298-299). 
Além dos redatores, o Farol Paulistano também contava com alguns colaboradores que esporadicamente lhe enviavam textos para publicação. Dentre estes se pode mencionar Manoel Joaquim do Amaral Gurgel, Manoel Odorico Mendes, Antonio Manoel de Campos Mello, Vicente Pires da Mota, João da Silva Carrão e Nicolau Pereira de Campos Vergueiro ${ }^{19}$, muito embora nenhum deles tenha aparecido nas páginas de $O$ Farol mais que uma ou duas vezes. Assim, dado o anonimato da maior parte dos textos publicados, revela-se insustentável qualquer afirmação no sentido de arrolar um corpo permanente de colaboradores de $O$ Farol.

O jornal era composto de seis partes básicas: o artigo do interior; as correspondências; as notícias nacionais e internacionais; os anúncios; as variedades; e a seção de publicação de documentos oficiais. Embora haja números em que uma ou outra seção não apareça, o Farol não alterou de forma significativa sua estrutura durante o período no qual funcionou. $\mathrm{O}$ artigo do interior $^{20}$ era redigido tanto pelos redatores do jornal como por seus colaboradores, e representava, na maior parte das vezes, o texto principal do periódico, cedendo essa importância apenas naquelas ocasiões em que era substituído por um artigo similar retirado de outra folha alinhada com as tendências políticas de $O$ Farol. De modo geral, tratava de questões mais abrangentes, quase sempre referentes ao andamento da política imperial, seja em sua acepção mais ampla, representada pela esfera pública da Corte, seja em sua dinâmica mais particular, condicionada à realidade das províncias e vilas. Outra forma assumida pelo "artigo do interior" era a de um libelo político, de modo que a defesa dos "princípios liberais" e da monarquia constitucional consistia no principal eixo teórico a ser apregoado, ao passo que as tendências "absolutistas", "despóticas" e "arbitrárias" compunham, por oposição, o principal campo teórico/prático a ser combatido. Nesse caso, os artigos recebiam nomes objetivos, de cunho pedagógico, a fim de identificar desde o princípio o teor do texto. ${ }^{21}$ Quando escrito por colaboradores, o "artigo do interior" recebia o título de "Artigo Comunicado", podendo ser publicado junto com algum texto menor do redator. Esses artigos costumavam ser menos abrangentes quando comparados aos redigidos pelos redatores, visto que tratavam de problemáticas mais delimitadas. Textos com esse perfil crítico direcionado a situações e indivíduos específicos eram corriqueiros entre os artigos comunicados, assemelhando-se, em certa medida, com as correspondências.

As correspondências compunham uma das principais seções de $O$ Farol. O redator deste por mais de uma vez alertou seus leitores de que o setor deveria ser preenchido com textos "úteis à causa pública”, e não por querelas e desafetos pessoais. ${ }^{22}$ Remetidas de diversas partes de São Paulo e até mesmo de Minas Gerais e Rio de Janeiro, as correspondências tratavam de assuntos variados, principalmente sobre a situação política ou econômica de determinada freguesia, vila, província e do Império como um todo. Nesse sentido, temáticas como o recrutamento militar, a infra-estrutura de transportes, as eleições, a justiça e o funcionamento do governo imperial 
ganhavam contornos tanto particulares como mais gerais, dependendo do enfoque dado pelo correspondente, que muitas vezes se revestia de um tom reivindicatório. Havia casos nos quais os redatores teciam algum comentário sobre a temática discorrida, geralmente com a intenção de corroborar com a ideia exposta pelo correspondente, ou fazerem-se endossados por ela. ${ }^{23}$ Os correspondentes também enviavam textos laudatórios, geralmente sobre as mostras de constitucionalidade das Câmaras Municipais ou da Câmara dos Deputados, críticas gerais ao “despotismo" e ao "absolutismo", impressões sobre a situação das instituições, excertos traduzidos e sugestões para o melhoramento da administração pública.

A despeito da heterogeneidade dos objetos tratados, bem como do número significativo de correspondências escritas em formato de artigo, a grande maioria delas se dividia em duas categorias: as que criticavam algo ou alguém e aquelas que se defendiam das acusações sofridas, contra-atacando-as ou não. Clérigos, militares, redatores, lentes do Curso Jurídico, juízes de paz, militares, capitães-mores, vereadores e ministros foram alvos constantes da pena dos correspondentes, o que demonstra uma tendência geral em tomar as pessoas públicas, sobretudo os empregados públicos, como responsáveis pelos rumos da nação. Mais do que criticarem pontos de vista, situações e atitudes, os correspondentes faziam questão de denunciar supostos abusos de autoridade e desvios de conduta no manejo da máquina pública. Urgia, segundo grande parcela desses correspondentes, a tomada de medidas legais que punissem tais homens, pois eram eles os causadores dos males da nação, e não o sistema político-administrativo em si.

Ora, se a publicação de correspondências que observavam com tanta clareza os empecilhos para o bom funcionamento do governo imperial pode sugerir, num primeiro momento, uma forma de $O$ Farol assegurar aos seus leitores um espaço próprio de enunciação, ela também permite entrever, por um outro ângulo, uma maneira indireta das folhas paulistanas acalentar em determinados questionamentos. Retirando de si a responsabilidade pela criação desses textos ${ }^{24}$, o redator de $O$ Farol deixava para que os próprios correspondentes, acusadores e acusados, esclarecessem suas posições no jornal, de modo que os debates fizeram-se recorrentes, e por vezes tiveram que ser encerrados pelo redator, que os julgou "pessoais" em demasia. A primeira dessas intervenções ocorreu já em abril de 1827, quando o redator notificou que não continuaria a "inserir tudo quanto quiserem escrever", referindo-se a uma discussão travada por correspondência entre o ouvidor de Itu e um missivista que o criticou por seu suposto abuso de autoridade, já que isso tiraria da folha "o logar que devem ter as matérias de instrução". ${ }^{25}$

Nesse âmbito, além de sua característica marcadamente político-pedagógica, os periódicos do período, sobretudo os liberais, desempenhavam a função de espaços de denúncia contra crimes de prevaricação, abuso de poder e outras irregularidades concernentes à gestão pública, o que era geralmente feitos por correspondentes. É provável que a maior parte das denúncias malograsse em 
seu intento, já que muitas das acusações careciam de profundidade argumentativa, diziam respeito a desavenças pessoais ou confrontavam com interesses de grupos influentes. Ainda assim, é inegável que se criou um locus de discussão permanente nesse sentido, sem mencionar os casos em que efetivamente as denúncias publicadas pelos jornais obtiveram algum resultado. Em abril de 1829, o redator de $O$ Farol Paulistano vangloriava-se de ter publicado uma correspondência cujas denúncias contribuíram para a remoção de Antonio Barbosa da Silva do cargo de Comandante da Freguesia do Bananal, sem deixar de reconhecer, todavia, ser comum a difusão de "calunias" pelos periódicos:

Agora acaba de haver uma próva sem réplica da utilidade da censura pública por meio dos Periódicos.

Consta-nos que o Capitão-Mór das Áreas em cumprimento da Portaria do Exm. Presidente o Sr. Almeida Torres, informara serem verdadeiros os factos criminosos, denunciados por um nosso Correspondente, e attribuidos ao $\mathrm{Sr}$. Capitão Antonio Barboza da Silva, Commandante da Freguesia do Bananal, que já fôra, segundo a Portaria que publicamos em nosso $\mathrm{N}^{\circ}$ antecedente, removido do commando, e que sem dúvida, será processado pela emenda sua, e escarmento, que taes forem. - Em quanto não tivermos um Presidente Constitucional, em quanto não foi feita a denuncia por uma Folha pública, ião todos os habitantes do Bananal gemendo ás escondidas do Sr. Barboza, sem que seus gemidos servissem por ventura senão de agravar seus males"[...] Não duvidamos, e maldade fôra negá-lo, que muitas calúmnias, que muitas falsidades se prapalão nos Periódicos, mas também grande maldade é não reconhecer a utilidade da liberdade d'escrever, ainda com esse não pequeno inconveniente, que tem o seu correctivo na mesma imprensa, publicando o calumniado a sua defeza, ou chamando o calumniador perante o competente juizo. ${ }^{26}$

Constatação importante é a de que enquanto o acusador se resguardava em pseudônimos, o acusado, quando respondia a uma denúncia, tinha que mostrar sua identidade, que por sinal já havia sido levada a público pelas insinuações a seu respeito. Foi justamente nesse sentido que políticos proeminentes do Império - notadamente da província de São Paulo - passaram a ocupar as páginas de $O$ Farol, isto é, não como propositores de ideias ou atitudes, mas como defensores de sua própria figura pública. Rafael Tobias de Aguiar ${ }^{27}$, Bernardo Pereira de Vasconcelos, José Arouche Toledo Rendon ${ }^{28}$, Manuel Joaquim de Ornellas Junior e Francisco de Paula Sousa ${ }^{29}$, apenas para citar nomes de maior projeção ${ }^{30}$. Caso típico ocorreu com Antonio Mariano de Azevedo Marques, um dos principais redatores de O Farol Paulistano e integrante dos Conselhos Geral e da Presidência da província de São Paulo a partir de 1830. Em março deste ano, o Mestrinho fez publicar nas páginas de $O$ Observador Constitucional uma correspondência na qual justificava seu pedido de dispensa do cargo de juiz de paz da Freguesia da Sé, situada na cidade de São Paulo. Alegando um "agravamento" de suas "moléstias" e uma suposta incompatibilidade entre o cargo para o qual fora eleito e suas ocupações de advogado e lente de Retórica no Curso Jurídico, Azevedo Marques utilizou-se da folha dirigida por Badaró para tornar de conhecimento público as 
motivações que o fizeram desistir do cargo, bem como para defender-se de insinuações que surgiram sobre o assunto. ${ }^{31}$

A seção de notícias nacionais e estrangeiras compunha uma parte menor de $O$ Farol, a qual era escrita por meio de artigos ou pequenas notas. As notícias nacionais, cujo material era amiúde extraído de periódicos fluminenses, voltavam-se basicamente para acontecimentos específicos, quase sempre de conotação política, ocorridos na Corte, embora fosse recorrente a publicação de notas sobre as províncias da Bahia, Pernambuco, Maranhão, Minas Gerais e sobre os conflitos no Sul. Já Portugal, França e Inglaterra ocupavam a maioria do noticiário internacional que, comumente retirado de folhas europeias, também contemplava as recém-formadas repúblicas americanas.

A seção de variedades constituía uma das mais diversificadas do jornal paulistano, uma vez que abarcava desde anedotas, causos e fábulas até pequenos ensinamentos morais, reflexões filosóficas e máximas políticas. A partir de meados de 1829, o Farol Paulistano começou a publicar notas sobre o movimento do porto de Santos, informações acerca da situação cambial das principais moedas europeias e americanas e tabelas de preços de produtos agrícolas exportados por São Paulo e Rio de Janeiro. Em ambos os periódicos, a parte mais significativa dessa seção ficava por conta dos excertos traduzidos de autores estrangeiros, tais como Benjamin Constant, Benjamin Franklin, J.J. Rousseau, Jeremy Bentham, Visconde de Chateaubriand, Conde Lanjunais, Sully, François Guizot e Jean-Baptiste Say. ${ }^{32}$ É provável que esses fragmentos fossem retirados de obras pertencentes ao próprio Costa Carvalho, dado que a biblioteca inventariada em 1838 após a morte de sua esposa, Genebra de Barros Leite, era considerada na época uma das maiores coleções particulares da cidade de São Paulo e continha grande parte dos autores publicados no Farol Paulistano e na folha de Badaró. ${ }^{33}$

A inclusão de trechos referentes a autores estrangeiros, sobretudo europeus e norteamericanos, era uma prática comum nos periódicos da primeira metade do século XIX ${ }^{34}$ Tal atitude desempenhava, num primeiro momento, a função de um artifício pedagógico para a disseminação de princípios políticos, visto que os periódicos facilitavam o acesso do público leitor aos autores estrangeiros por meio de dois elementos básicos: em primeiro lugar, como observado, o jornal era mais barato e mais fácil de ser comprado se comparado a um livro; além disso, o formato pouco extenso dos trechos publicados fornecia a um público majoritariamente sem o hábito da leitura um texto previamente selecionado e recortado pelo redator, o que lhe conferia maior inteligibilidade. As próprias traduções, nesse sentido, não estavam livres de sofrerem manipulações e reinterpretações por parte daqueles que queriam imputar-lhe algum significado. ${ }^{35}$ Como notou o então redator de $O$ Farol, em 1828, a inserção de traduções de autores estrangeiros fazia parte de um "plano" da folha paulista para a "ilustração" de seus leitores: 
Muito tempo ha, que não damos algumas traducções aos nossos leitores, sendo esse um dos pontos do nosso plano, e conhecendo nós a muita vantagem, que d'esse trabalho póde resultar ao público, o qual pela mór parte não tem, nem pode obter certos livros já por sua raridade, já pelo seu preço, a tambem a muita gente acontece não ter algum, por desuso, e não ser essa sua profissão, outros pelo contrário, as vezes inteiramente diversa, de lêr um grosso volume, mas achando em um pequeno artigo de um Periodico aquellas verdades que se tornariam incomodas, espalhadas em um volume, as lerão com prazer, as reterão, e irão adornando o seu espirito, e ficando mais nas circunstancias de conhecerem seus deveres, e direitos, e por consequencia o que devem fazer, e exigir, e a opinião publica irá sendo por mais illustrada, mais valente e fixa, mais formidavel aos despotas, e mais proveitoza à sociedade. ${ }^{36}$

A tradução de autores portadores de matizes teóricas e objetivos distintos, como Rousseau, Benjamin Constant e o Visconde de Chateubriand, e a inserção sistemática dos excertos no corpo do periódico revelam, todavia, um emaranhado de aspectos que superam a atitude de "fornecer luzes" para a população. Juntamente com essa finalidade coexistia uma intenção de ordem prática que instrumentalizava o autor citado, isto é, utilizava-o seja como recurso legitimador de um discurso proferido pelo periódico seja como esclarecedor de um evento ocorrido na província de São Paulo ou em outras localidades do Império. Em setembro de 1828, ao levar a público um artigo anônimo traduzido com o título de "Principal causa da corrupção dos Príncipes", que discorria sobre perniciosidade daqueles que adulam incondicionalmente a figura dos monarcas, o Farol não estava condenando os elementos em si causadores da degeneração política dos príncipes; estava sim criticando o círculo político de D. Pedro, por essa época notabilizado por figuras como João Carlota, Plácido Abreu e, sobretudo, pelos polêmicos Francisco Gomes da Silva - o "Chalaça" - e João da Rocha Pinto, ambos secretários do imperador. ${ }^{37}$

Os anúncios compunham a seção menos extensa da folha, o que não significa que tivessem pouca importância, dada sua constância e variedade. Anunciava-se a venda de artigos avulsos de toda sorte (livros, bebidas, móveis, vestimentas, calçados, instrumentos musicais, armas e objetos pessoais), quer por particulares quer por negociantes; a abertura ao público de novos estabelecimentos (padarias, botequins, boticas, fábrica de chapéus, vendas de secos e molhados, e lojas de artigos diversos); terrenos, casas e fazendas para a venda; avisos sobre datas nas quais correria a loteria promovida pela Santa Casa de Misericórdia da cidade de São Paulo; e prestações de serviços diversos (advocacia, tratamento médico e dentário, aulas de línguas estrangeiras, matemática e dança, conserto de instrumentos musicais, costura e criação de cavalos). A despeito de estarem associados, em sua grande maioria, à cidade de São Paulo, alguns desses anúncios não se atrelavam diretamente ao universo paulistano, de modo que não eram raros aqueles vindos de outras localidades da província, especialmente de Santos e Itu. Os anúncios vindos de outras províncias do Império, todavia, eram publicados de forma bastante esporádica. 
Os anúncios mais recorrentes eram aqueles relacionados à venda, compra e fuga de escravos. Quase sempre nomeados - inclusive por indivíduos de projeção pública, tais como Nicolau Pereira de Campos Vergueiro, José da Costa Carvalho, Rodrigo Antonio Monteiro de Barros ${ }^{38}$ e Domitila de Castro e Canto Melo, a Marquesa de Santos -, esses pequenos textos tinham como objeto, em sua maior parte, a fuga de cativos, de modo que esses eram descritos fisicamente com o intuito de serem reconhecidos e capturados. Também era comum a publicação pelo $O$ Farol de notas emitidas por juízes de paz quando da captura de escravos foragidos.

O Farol, além disso, levava a público seus próprios anúncios, que tratavam de obras impressas postas à venda na tipografia do jornal. Excetuando o Compendio Scientifico para a Mocidade Brazileira destinado ao uso dos dois $\operatorname{sexos}^{39}$, anunciado por 2:000 rs. em 1827, o restante das obras vendidas na Tipografia do Farol Paulistano continha expressa conotação política. A mais abrangente delas era o Dialogo constitucional Braziliense, que agregava "todas as leis e disposições regulamentares da Constituição política do Império, e das eleições", bem como “os regimentos do Conselho d'Estado e um mui bem ornado mappa de todas as garantias, que a mesma constituição offerece effectivas aos cidadãos brazileiros". ${ }^{40}$

A seção que publicava documentos oficiais era a única parte do jornal cujo domínio do material não era exclusivo dos dois jornais paulistas. Por ser a única na cidade até 1831, a tipografia de Costa Carvalho era obrigada, por lei, a publicar documentos oficias, como atos emitidos pela Secretaria do Governo, atas das sessões do Conselho da Presidência e do Conselho Geral, todos eles da província de São Paulo. Tais documentos eram na maior parte das vezes publicados sem qualquer comentário dos redatores, o que demonstra certa reticência dos redatores no que se refere à obrigatoriedade do serviço prestado, mais precisamente em relação aos atos do executivo do governo provincial. Em mais de uma ocasião o Farol expôs seu "incômodo" na publicação desse tipo de documentação, chegando a sugerir, "ousadamente", que se instalasse uma tipografia do Governo direcionada para esse tipo de tarefa. ${ }^{41}$ Segundo nota publicada em julho de 1830, além de tomar o espaço do jornal, parte desses documentos tinha pouco proveito, haja vista os recorrentes atrasos no envio dos mesmos à Tipografia do Farol Paulistano, demora essa que, no caso de editais, acabava por torná-los inúteis à causa pública. ${ }^{42}$ Críticas semelhantes foram feitas por $O$ Observador Constitucional, que assinalou a "antiquissima data" dos documentos enviados pelo governo da província para a publicação. ${ }^{43}$

Mas nem todos os documentos publicados pelo $O$ Farol eram lamentados pelos redatores, o que demonstra o interesse da folha de Costa Carvalho em outro tipo de documentação oficial que não aquela veiculada pelo Governo da província. Privilegiava-se, na esfera central, os trabalhos da Câmara dos Deputados - projetos de lei, discursos proferidos durante as sessões, pareceres emitidos pelas comissões especiais -, ao passo que na esfera local eram publicadas atas das sessões das 
Câmaras Municipais de São Paulo e Itu, localidade onde Costa Carvalho e seus correligionários possuíam fazendas de cana-de-açúcar e relações pessoais privilegiadas (HOLANDA, 1964, p. 415472). Além disso, nem toda a documentação oficial publicada nos periódicos era de caráter obrigatório. Em fevereiro de 1830, o Observador Constitucional passou a publicar as atas da Câmara Municipal de Parnaíba após essa fazer uma solicitação à folha de Líbero Badaró para incluir seus trabalhos. $^{44}$

Os leitores dos dois jornais compunham um grupo bastante heterogêneo, representando distintos grupos sociais. A partir das correspondências insertas na folha paulistana, é possível notar uma gama de indivíduos com ocupações diversas, tais como médicos, caixeiros, negociantes, tropeiros, clérigos, militares, professores de primeiras letras e do Curso Jurídico, estudantes e toda sorte de empregados públicos, desde fiscais de Câmaras Municipais, vereadores e juízes de fato até juízes de paz, membros do Conselho da Presidência da província de São Paulo e deputados. Tais segmentos compunham, grosso modo, o espectro de votantes e eleitores da província de São Paulo. Isso sem contar os anunciantes do jornal - padeiros, sapateiros, costureiras, donos de mercearias e outros tipos de vendedores e artesãos -, que podem ser tidos, virtualmente, como leitores das folhas paulistanas.

Não obstante ambos os periódicos fossem impressos na cidade de São Paulo, seu meio de circulação se estendia muito além daquele circunscrito à capital da província. Ao consultar as diversas seções dos dois jornais, é possível constatar uma imbricada teia de relações estabelecida entre as folhas criadas por Costa Carvalho e Líbero Badaró e setores não radicados somente na cidade de São Paulo, como redatores de outros jornais, correspondentes, anunciantes, assinantes, leitores esporádicos e funcionários vinculados às instituições oficiais. Esses eram provenientes de outras regiões do planalto e litoral paulistas ou até mesmo de outras províncias, tais como Rio de Janeiro e Minas Gerais.

$\mathrm{Na}$ maioria dos casos, o contato entre o público e o jornal se dava por meio de correspondências que, se tomadas em conjunto e diacronicamente, revelam um paulatino processo de ampliação do campo de alcance de $O$ Farol em São Paulo bem como em outras províncias. Só no ano de 1827, participaram da seção de correspondências de $O$ Farol leitores da capital paulista, das Vilas de Santos, Cubatão, Itu, São Carlos, Porto Feliz, Itapeva, Iguape, Constituição, Sorocaba, Ipanema, e da própria cidade Rio de Janeiro. Em 1828, o perfil dos correspondentes se tornou ainda mais amplo, de modo que surgiram cartas de habitantes das Vilas de Jundiaí, Franca do Imperador, Mogi-Mirim, Curitiba, Taubaté, Areias e Lorena, como também das freguesias de São Bernardo, Nossa Senhora Conceição de Guarulhos e Cotia (pertencentes à Vila de São Paulo), e de Santo Antonio da Parahibuna, vinculada à Vila de Jacareí. Um ano depois, surgiram cartas das vilas de Mogi das Cruzes, Bananal, Guaratinguetá, Antonina, Itapetininga, Campos de Goitacases (Rio de 
Janeiro) e da Freguesia de Pirapora (Vila de Constituição). Em 1830, foram publicadas correspondências das Vilas de Bragança, Ubatuba, Bela, São José, Paranaguá, Atibaia, Caldas (Minas Gerais), Rezende (Rio de Janeiro), e da freguesia de São Roque, pertencente à Vila de Paranahyba.

Esse movimento de ampliação e diversificação da seção de correspondências significava, por um lado, um aumento no número de leitores dos jornais, e por outro, uma atitude promovida por $O$ Farol no sentido de abrir canais de comunicação entre os periódicos e outras vozes, quer da província de São Paulo quer das demais, criando assim um espaço comum de reflexão sobre as questões tidas como pertinentes pelos redatores da folha, notadamente $\mathrm{o}$ andamento da administração pública no Centro-Sul do Império. É necessário, todavia, que se pondere o papel das correspondências, dado que parte delas poderia ser forjada pelos próprios redatores.

Tal abertura, contudo, não parece ter sido mera deliberação da redação de $O$ Farol, mas produto de uma comunhão ou mesmo de uma troca de interesses entre os jornais e o corpo de correspondentes, dado que para ampliar o seu número de leitores, o periódico tinha de concederlhes espaço em sua folha. Os correspondentes, por sua vez, cobravam do jornal que esse "lançassem suas luzes" em diferentes localidades, evocando em determinados casos os objetivos traçados pela folha em seus primeiros editoriais. Em 1827, um correspondente anônimo de Ipanema reclamava por uma atitude de $O$ Farol em relação à situação da Fábrica de Ferro de Ipanema:

Sr. Redactor - No prospecto de sua Folha, prometteu-nos Vm. fallar em todos os estabelecimentos d'esta Província, fazendo chegar a mercê da luz do seu Farol, ao conhecimento do publico o bom, ou máo andamento d'elles, elogiando, ou censurando o condutor dos empregados. Mas, Sr. Redactor, já lá vão 54 nºs, e ainda não se dignou lançar um golpe de vista sobre as margens do Ypanema, subir a altura do Arassoyáva, visitar a Imperial Fabrica de Ferro!! Tão pouco lhe merece este estabelecimento colossal, o primeiro e mais interessante da Província, e talvez de todo o Brazil? Entretanto o que por lá váe!!. ${ }^{4}$

Outras circunstâncias ajudavam a promover o alargamento do alcance dos dois periódicos paulistas. A Sociedade de Guaratinguetá, uma das muitas sociedades criadas nesse período, tinha como uma das suas prerrogativas "assignar os Periódicos d'essa província", que poderiam ser consultados por qualquer cidadão. ${ }^{46}$ No final de 1830 , ano da fundação da Sociedade, esta enviou ao Farol um arrazoado das atividades desenvolvidas ao longo daqueles meses, dentre as quais estava a leitura pública de alguns periódicos "liberais", tais como a Aurora Fluminense, a Voz Fluminense, o Manual das Brasileiras, o Pregoeiro, o Observador Constitucional e a própria folha de Costa Carvalho. ${ }^{47}$

$\mathrm{O}$ ato de assinar periódicos por um dado órgão ou instituição consistia numa prática comum na época, especialmente para as esferas oficiais de poder, como as Câmaras Municipais. Conforme a lei de $1^{\circ}$ de outubro de 1828 que regulamentou o funcionamento das municipalidades, essas 
ficaram obrigadas a assinar os diários dos Conselhos Gerais e das Câmaras legislativas e os periódicos que publicassem os extratos de suas sessões. ${ }^{48}$ Em agosto de 1832, o presidente da província de São Paulo enviou um ofício à Câmara Municipal de São Paulo solicitando informações sobre o cumprimento da referida disposição, o qual foi respondido positivamente. ${ }^{49}$

A publicação de excertos de $O$ Farol por outros jornais consistia em mais uma forma de proliferação do discurso desses periódicos. Única folha paulista até outubro de 1829, o Farol era, segundo o Astro de Minas, um dos periódicos mais lidos do Império, sendo inclusive traduzido na Europa, fato esse que causava inveja à Gazeta do Brasil, jornal alinhado ao governo central que, como se verá adiante, foi o primeiro adversário de $O$ Farol na imprensa:

[...] mas enfim a gazeta urra de raiva, e inveja, porque apenas conta 200 assignantes, e daquelles, que publicou o nome Patrício o Sr. Ledo entretanto que a Astréa se vai regalando com os seos $1 ; 400$ assignantes, cujo $\mathrm{N}$. cresce diariamente. Não esqueça a viperina lingoa da gazeta esse excellente periódico Paulistano $=O$ Farol $=$ mas o Farol he lido com avidez em todo o Brasil, e na mesma Europa culta, onde se tem reimpresso e em diversas lingoas ${ }^{50}$

É manifesto que a fala do periódico contém elementos retóricos e propagandísticos, mas ainda assim revela o alcance das folhas paulistas. O próprio Astro de Minas publicaria no ano seguinte uma nota onde dizia que as folhas Farol Maranhense, Abelha Pernambucana, Diário de Pernambuco, Cruzeiro, Amigo do Povo, Gazeta Parahybana, Bahiano, Diário Fluminense, Aurora Fluminense e o Farol Paulistano estariam disponíveis “para quem quizer ler” na Biblioteca Pública de São João Del Rei. ${ }^{51}$ Um ano depois, os também mineiros O Universal e Estrela Marianense publicaram anúncios referentes ao gabinete de leitura situado na residência padre Antonio José Ribeiro, em Mariana, Minas Gerais, local onde se disponibilizavam para a leitura periódicos do Rio de Janeiro, São Paulo e Minas Gerais (SILVA, 2006, p. 50).

Alguns empecilhos comprometiam, entretanto, uma circulação mais regular das duas folhas paulistas. O principal deles era a precariedade das linhas de correio que, nesse período, ainda estavam se constituindo e não cobriam boa parte das freguesias das províncias. Não eram poucas as correspondências que criticavam a morosidade na emissão de cartas ou que reclamavam a implantação de uma linha regular de correios entre duas localidades. ${ }^{52}$ Em 1830, um correspondente acusou o Administrador do Correio da vila de Resende, Rio de Janeiro, de "abrir as folhas" endereçadas a estranhos, para primeiro lê-las e depois enviá-las a seus respectivos assinantes, o que ocasionava sucessivos atrasos na entrega dos jornais. ${ }^{53}$

\section{Permanências e rupturas: a atuação política de $O$ Farol Paulistano}

A maior parte dos impressos surgidos a partir de 1826, quando da convocação da primeira legislatura do Império, alinhava-se aos preceitos mais gerais do liberalismo, tendência que se 
acentuou no ano seguinte com o acirramento do enfrentamento entre a Câmara dos Deputados, o Senado e o Ministério, especialmente no que se referia à política fiscal do Império. Se projetos importantes como o que responsabilizava o Conselho de Estado e o Ministério pelos seus atos, o estabelecimento dos Cursos Jurídicos em São Paulo e Olinda, a regulamentação dos Conselhos Gerais de província e das Câmaras Municipais, e a criação do Juizado de Paz foram discutidos por ambas as Câmaras e votados posteriormente, a definição de uma política econômica que contemplasse a questão orçamentária e tributária gerava grandes embates sobre os destinos do Tesouro do Brasil. O aumento da dívida pública, os termos pelos quais foram adquiridos empréstimos no exterior antes da convocação do Legislativo, o crescimento das despesas com a campanha no Sul e a possibilidade de aumento da carga tributária eram questões ao mesmo tempo substantivas e contraditórias, e que opunham, principalmente, deputados e ministros. Estes pleiteavam um acréscimo no orçamento para as pastas ministeriais, bem como um incremento na carga tributária, ao passo que aqueles, organizados desde 1826 numa Comissão dirigida para o exame dos negócios financeiros e diplomáticos, refutavam a ampliação de tributos e exigiam a prestação de contas do Ministério em relação a seus gastos (DOIN, 1986).

O ganho de espaço pelos liberais por meio da imprensa deu-se tanto no Rio de Janeiro como em outras províncias. Na Corte, surgiram periódicos como a Astréa (1826) e Aurora Fluminense (1827); em Minas Gerais, o Astro de Minas (1827), que teve influência de o Universal (1825); em São Paulo, o Farol Paulistano (1827); e no Maranhão, o Farol Maranhense e A Minerva, os dois criados em 1827 (SODRÉ, 1966).

De modo geral, esses jornais se afinavam com a oposição feita pela Câmara dos Deputados ao governo de D. Pedro e, em determinados pontos, ao Senado, de forma que parte de seus redatores era composta por membros da própria Casa, como Evaristo da Veiga (Aurora Fluminense) e Batista Caetano de Almeida (Astro de Minas), deputados por Minas Gerais na segunda legislatura, Bernardo Pereira de Vasconcelos (O Universal), deputado por Minas Gerais nas duas primeiras legislaturas, José da Costa Carvalho (O Farol Paulistano), deputado pela Bahia nas duas primeiras legislaturas, Manoel Odorico Mendes (colaborador de $O$ Farol Paulistano que já havia redigido em 1825, em São Luis do Maranhão, o liberal Argos da Lei), deputado pelo Maranhão nas duas primeiras legislaturas, e José Joaquim Vieira Souto (Astréa), deputado pelo Rio de Janeiro na segunda legislatura (TAUNAY, 1950, p. 115-122). Alguns dos nomes citados, como pode ser observado, só seriam deputados na segunda legislatura (1830-1833), fato que reitera a importância da imprensa como instrumento de projeção política.

Qualificados pela bibliografia como liberais "moderados", terminologia utilizada pelos próprios coevos, os setores envolvidos na publicação desses periódicos bem como no estabelecimento da oposição parlamentar ao governo de D. Pedro julgavam-se adeptos da 
"moderação", conceito que se apresentava, frequentemente, mais como um instrumento analítico das diversas esferas da sociedade civil organizada do que uma posição política rigorosamente demarcada (MOREL, 2005, p. 117-118). Espécie de visão de mundo baseada no "justo equilíbrio" das coisas - uma releitura, dentre outras influências, da concepção de just milieu empregada pelos liberais franceses das primeiras décadas do século XIX, que buscava fixar um ponto de equilíbrio entre a estrutura sócio-politica do Antigo Regime, o legado iluminista e a experiência revolucionária de 1789 -, a "moderação" aproximava-se, nesse sentido, das noções mais amplas da Razão ilustrada (MOREL, 2005, p. 119-120). No campo político, assim definiu-a a Aurora Fluminense, um dos periódicos liberais mais influentes durante o Primeiro Reinado e início do período regencial:

\begin{abstract}
A moderação em política não é senão a prudência reguladora, que, modificando as opiniões sociais extremas, as chama ao justo meio-termo, ou antes que dá aos objetos o seu devido valor, sem deixar-se fascinar pelo calor do entusiasmo ou pelo prisma das paixões do momento ${ }^{54}$
\end{abstract}

Para os "moderados" a busca pelo meio-termo da política passava, necessariamente, pela criação de um aparato jurídico-administrativo que proporcionasse ao mesmo tempo a divisão dos poderes, a criação de instituições representativas, a limitação da atuação dos governantes e a manutenção dos direitos de cidadania, sem pleitear, todavia, uma organização social que ampliasse o espaço de cidadania já assegurado pela Carta de 1824 (BASILE, 2006, p. 64). Tratava-se, como ressaltou Marcello Basile, de salvaguardar um pacto social a partir da lógica jusracionalista de autores clássicos do liberalismo como John Locke:

\footnotetext{
Opondo-se ao jusnaturalismo aristotélico-tomista e apoiando-se no jusracionalismo de matriz lockiana, sustentavam os moderados que os direitos naturais universais dos indivíduos encontravam seus limites na organização da sociedade mediante o pacto social, e que, para além das leis naturais metafísicas, o direito racional positivo deveria, concreta e utilitariamente, conformar-se ao bemestar da nação. ${ }^{55}$
}

Referências teóricas acerca da organização do Estado eram constantemente compartilhadas por redatores e seus correligionários políticos, o que não significa que convergissem para a formação de uma plataforma político-ideológica comum e claramente definida. Não obstante os "moderados" verem na Carta de 1824 a garantia da liberdade, da legalidade e da propriedade, ou seja, elementos necessários para a construção de um estado liberal, isto não lhes afiançava, necessariamente, uma univocidade política (RIBEIRO, 2006).

Um dos pontos que melhor exemplificam a inexistência de um substrato político compartilhado entre os "moderados" está na falta de consenso entre seus representantes quanto à estrutura da monarquia brasileira. Pendendo, sem extremismos, entre a centralização e a 
descentralização do Estado, os "moderados" mostraram-se hesitantes para com a reforma constitucional iniciada após a Abdicação que culminou na lei de 12 de outubro de 1832 e, posteriormente, no Ato Adicional de 1834, o que contribuiu para seu paulatino enfraquecimento durante a segunda metade da década de 1830. Em novembro de 1834, o periódico O Justiceiro, dirigido pelo padre Diogo Feijó, indicou que duas das fraquezas dos "moderados" seriam justamente a falta de um posicionamento mais enérgico e a tendência a portar-se de forma hesitante sobre os assuntos da política:

\footnotetext{
Este partido, o dos moderados, é poderoso, por seu número, porque conta com a nação, cujos votos e opiniões representa; pela santidade da causa que defende, que é a propriedade nacional e ainda mesmo por seus princípios, porque detesta excessos; porém, em honra da verdade, não tem sabido aproveitar-se das circunstâncias. Semelhante aos médicos da medicina expectante, esse partido não obra, pisa sempre o mesmo terreno, teme de todas as medidas, ele não enxerga em tudo quanto se lhe propõe senão fraqueza ou energia em excesso; sempre esperando, sempre irresoluto, contenta-se no momento da crise com um ato de meia medida que só se encaminha a acobertar o mal e deixá-lo criar profundas raízes. Como existe hoje, julga ter direito a existir amanhã, e a sua prova favorita é lançar em rosto aos que pressagiam mal de sua apatia. ${ }^{56}$
}

$\mathrm{Na}$ realidade, a constante busca por um meio termo nas ações políticas ocultava um problema de natureza mais profunda, que era o da multiplicidade de usos e interpretações do liberalismo (GUIMARÃES, 2001). De todo o modo, a atuação dos "moderados" dentro e fora das esferas oficiais de poder acabou sendo crucial para sua consolidação como força política dotada de alguns princípios mais ou menos comuns. Porta-vozes da oposição ao governo de D. Pedro, os “moderados" não questionavam as diretrizes básicas asseveradas pela Carta de 1824, embora vislumbrassem contrabalançar a preeminência do monarca por meio da ampliação da atuação da Câmara dos Deputados na política imperial. Ao defenderem o cumprimento desse documento, apregoavam a monarquia constitucional representativa, a participação contundente do Legislativo, a legitimidade das ações políticas e a ideia de que as mudanças político-administrativas fossem operadas de forma gradual e dentro das esferas oficiais de poder (CASTRO, 1978).

Partindo da primazia da "opinião" na configuração das sociedades da época, o Farol Paulistano justificou sua publicação a partir da função da imprensa, compreendendo-a como o “mais útil e preciso invento do homem" e portadora de duas características essenciais. A primeira delas, mais quantitativa, referia-se à forma rápida com que os impressos podiam disseminar ideias, atingindo assim um maior público em um menor período de tempo. A segunda, de ordem qualitativa, dizia respeito à proeminência da imprensa enquanto defensora da liberdade, da Independência do Brasil e do caráter constitucional por ela assumido, chegando a ponto de naturalizar o meio impresso como veículo das ideias liberais vigentes no início do século XIX: 
[...] Mas quem espalha a opinião, quem a faz medrar, quem a uniforma, quem the ateia os gritos, quem lhe presta as suas vigorosas e longas azas com que tem percorrido em tão pouco tempo o universo inteiro?

É sem dúvida a imprensa o mais útil e preciso invento do homem, o baluarte da liberdade, o terror dos déspotas, a protetora da humanidade. O Brasil disse que queria ser livre e a sua independência foi o primeiro fruto do sistema constitucional que abraçou para nunca mais deixar [...] Foi a imprensa companheira e auxiliadora da liberdade quem fez a nossa independência. Grandes louvores e gratidão eterna aos denodados escritores que nessa época apareceram. O Brasil é independente e continua a querer ser livre $\left[\ldots . .{ }^{57}\right.$

Mas seria esse, em linhas gerais, o programa que o Farol seguiria durante seus quase cinco anos de circulação, estimulado pela divisa La liberté est une encleme qui usera tous les marteaux (a liberdade é uma bigorna que desgastará todos os martelos), que acompanhava o cabeçalho do jornal?

De forma unânime, autores como Afonso de Freitas, Lafayette de Toledo, Affonso de Escragnolle Taunay, Nelson Werneck Sodré, Arnaldo Contier e Augustin Wernet tomaram o Farol Paulistano como um jornal cujas orientações político-ideológicas se alinhavam com a intitulada ala "moderada" dos liberais do Primeiro Reinado e Regências, aproximando-o de outras folhas com perfil semelhante publicadas no período, tais como a Aurora Fluminense e a Astréa, do Rio de Janeiro, e o Astro de Minas e o Universal, de Minas Gerais. Imbuído do espírito daqueles que compunham a oposição ao governo de D. Pedro e que chegariam ao poder após a Abdicação, o Farol Paulistano teve como principal bandeira, segundo esses autores, a defesa dos princípios monárquico-constitucionais contra o "despotismo" e o "absolutismo" que ainda perpassavam setores da administração do Estado, notadamente do Poder Executivo (CONTIER, 1978; FREITAS, 1928; SODRÉ, 1966; TAUNAY, 1956; TOLEDO, 1898; WERNET, 1978).

Por não ter sido estudado em sua completude por nenhum desses autores, o Farol Paulistano deixou de receber um tratamento minucioso de forma e conteúdo, o que simplificou o entendimento sobre seu discurso e retirou-lhe parte da historicidade intrínseca a qualquer periódico, que é o fazerse no dia-a-dia. Atribuir à folha de Costa Carvalho uma diretriz liberal moderada inequívoca, sem atentar para as alterações ocorridas em seus artigos ao longo do tempo, acabou por tornar homogêneo aquilo que não fora outrora, ou seja, atribuiu-se um caráter rígido e constante a algo que nunca foi um dado a priori, mas sim um processo em construção permanente que se subjugou às vicissitudes da luta política deflagrada dentro e fora do Legislativo, bem como dentro e fora do governo provincial. Analisando a questão por outro ângulo, imputar ao Farol esse tipo de característica é lançar mão, também, de um raciocínio teleológico cujo sentido reside na associação entre a oposição liberal ao governo de D. Pedro e ascensão dos moderados após o 7 de abril, o que revestiria a folha paulista de uma coerência política que, de fato, não se evidenciou na leitura por nós realizada. 
Não se pretende aqui refutar as peculiaridades acima mencionadas sobre a primeira folha paulista, mas entendê-las como integrantes de um movimento que se processou no transcorrer do tempo da política, com rupturas e permanências, e que foi condicionado tanto pelo crescimento paulatino de seu público leitor como pela discussão levada adiante no âmbito provincial e na Corte. Num período em que a institucionalização do governo e do Estado constitucionais marchou em paralelo e conflituosamente com a prática política cotidiana dos poderes locais, haja vista os problemas em torno da regulamentação e aplicação das leis sobre os Juizados de Paz, das Câmaras Municipais, dos Conselhos Gerais de província e do Código Criminal, o Farol participou do jogo político de modo sinuoso. Ou seja, equacionou seu discurso a partir dos interesses dos grupos locais a ele associados e da possibilidade de viabilização de um projeto de monarquia constitucional em bases liberais, conduta essa que nos permite matizar uma suposta univocidade da folha de Costa Carvalho.

Deste modo, o Farol Paulistano pode ser dividido em três momentos que constituem menos uma sequência cronológica rígida do que uma sucessiva incorporação e re-significação de princípios.

O primeiro deles se deu entre o início da circulação do periódico e até por volta de maio de 1828, e teve como principais características a definição de um padrão discursivo (de forma e conteúdo), a busca por um espaço na esfera pública da imprensa periódica e a demarcação de um cenário político conflituoso, no limite bipolar, entre "liberais" e "constitucionais" versus “absolutistas" e "corcundas". Na prática, isso significou a publicação de artigos maniqueístas e de alto teor pedagógico, o alinhamento ou o afastamento em relação aos principais periódicos em circulação na Corte e em outras províncias, e a fixação de uma leitura própria sobre o andamento dos negócios públicos do Império, adotando-se critérios valorativos para a análise dos poderes Executivo (reacionarismo do Ministério versus constitucionalismo do monarca), Legislativo (apreciação da Câmara dos Deputados versus depreciação do Senado) e Judiciário (precariedade das formas antigas versus viabilidade das inovações propostas).

Única folha paulista em circulação durante esse período, o Farol entrou em confronto direto com periódicos fluminenses de orientação governista. Durante o ano de 1827 e os primeiros meses de 1828, o Farol Paulistano discutiu abertamente com a Gazeta do Brazil, periódico dirigido por João Maria da Costa e José Joaquim de Carvalho. Ao defender o Gabinete instituído em 15 de janeiro de 1827 (JACQUES, 1982, p.75), a Gazeta notabilizou-se por suas insistentes críticas feitas à Câmara dos Deputados e seus componentes, colocando-se em uma posição declaradamente próimperador. $^{58}$

Logo após o surgimento da Gazeta do Brazil, o Farol Paulistano emitiu suas impressões acerca da nova folha fluminense, apontando para o seu caráter combativo: 
Recebemos n'este correio o $1^{\circ} \mathrm{n}^{\mathrm{o}}$ da Gazeta do Brazil, novo Periodico publicado no Rio de Janeiro no dia 30 do proximo-passado [...] O novo Periodico é escripto em estilo raivoso, e virulento; e a pesar de se mascarar com o nome de Constituição, que se conhece sair-lhe menos voluntariamente da penna do que o de Jacobinismo, parece destinado a atacar tudo quanto o Brazil tem de mais caro, tudo em que elle põe suas mais seguras esperanças. Elle quer defender a torto e a direito o Ministério, e toma demaziado a peito a defesa do Ministro da Guerra, que assaz tem patenteado sua instabilidade na direção da guerra atual [...] Ataca com rancôr as Camaras, que formão a Assemblea Geral, desfigurando os fatos, e até mentindo imprudentemente, affirmando deliberações que nunca forão tomadas, antes tomadas pelo contrário [...] Espalha o alarma, nos póvos, dizendo que a Camara dos Deputados põem o pé no sanguinolento terreno do Jacobinismo; que existem Clubs da natureza a mais perigosa. ${ }^{59}$

Dentre os aspectos assinalados pelo jornal de Costa Carvalho a respeito da Gazeta, é de se notar aquele que indica a contradição da folha fluminense ao se intitular "Constitucional", já que, segundo o redator de O Farol, seu estilo "raivoso" e "virulento" só contribuiria para "atacar" o constitucionalismo brasileiro. Ao analisar a inserção da Gazeta na imprensa periódica do período, autores como Afonso Taunay e Werneck Sodré também ressaltaram tal incoerência, especialmente por se tratar de um jornal vinculado aos "restauradores" (TAUNAY, 1961, p. 114; SODRÉ, 1966, p. 114-115). Contudo, segundo Morel, essa contradição que também esteve presente em outros periódicos defensores do Governo de D. Pedro - como o Diário Fluminense e o Despertador Constitucional Extraordinário - congrega outros elementos que a tornam mais complexa, uma vez que "constitucionalismo" e "liberalismo" desempenhavam significados distintos no vocabulário da época. Para o autor, periódicos como a Gazeta do Brasil buscavam conferir aos liberais o estatuto de "Carbonários", "Jacobinos", "Demagogos", isto é, de setores que ofereciam perigos ao bom funcionamento da Carta de 1824, em especial às atribuições de poder referentes ao monarca. Em contrapartida, alguns periódicos moderados como a Astréa notaram a manobra política dos "corcundas", que se deslocaram da posição de "anti-liberais" para a de "constitucionais", forjando assim um posicionamento político supostamente alinhado com a Carta Magna. Conforme Morel, esse pretenso "constitucionalismo" apoiava o texto de 1824 com a condição de que esse mantivesse reforçado o poder do monarca, constituindo assim um dos eixos centrais para a compreensão do movimento restaurador do período pós-Independência (MOREL, 2005, p. 134).

O momento seguinte se estendeu, aproximadamente, entre maio de 1828 e meados de 1830, e apresentou uma complexificação geral de $O$ Farol Paulistano. A investida no conflito ideológico entre liberalismo e absolutismo refreou-se, ao passo que as críticas em relação ao Ministério ganharam força, gerando inclusive problemas jurídicos para o jornal. ${ }^{60}$ A despeito de ter mantido os juízos de valor sobre os empregados públicos e políticos, as críticas emitidas pelo Farol tornaramse mais substantivas, incidindo sobre pontos centrais do processo de organização do aparelho estatal e da discussão vinculada ao Parlamento, tais como a regulamentação dos Conselhos Gerais e das 
Câmaras Municipais, a questão tributária, do Banco do Brasil e o início da elaboração do Código do Processo Criminal. Em decorrência da instalação dos Conselhos Gerais de província, em 1828, e da discussão em torno do seu regimento, a política provincial passou a ser a matéria mais comum das páginas de $O \mathrm{Farol}$, o que até então ocorrera apenas esporadicamente. Além disso, por conta da conduta hesitante do Governo em relação à sucessão do trono português e da inclinação governista de algumas folhas escritas por franceses na Corte, como o Courrier du Brésil e o Jornal do Comércio, virou pauta recorrente do jornal paulista a crítica à intromissão dos estrangeiros nos negócios brasileiros.

O embate com os periódicos fluminenses que advogavam em favor de D. Pedro e seu governo acentuou-se. Com o Censor Brasileiro - periódico que circulou na capital do Império entre maio e julho de $1828^{61}$-, o Farol discutiu, sobretudo, a atuação do Senado na Assembleia Geral. Segundo a folha de Costa Carvalho, o Censor era "moderado nas expressões, mas nem tanto na matéria", pois se colocava como "aliado do Senado" e reprovava os comentários de O Farol sobre a segunda Casa. O Censor condenava as afirmações de O Farol sobre o Senado por serem generalizantes, o que não condizia com sua diversidade de integrantes e de posicionamento político. O Farol acreditava, ao contrário, que suas críticas eram válidas, por não se tratar de um ataque à instituição senatorial, mas sim ao "modo de obrar" do Senado. Embora contestasse o posicionamento governista de $O$ Censor, o Farol afirmou que esse nunca atacou a Constituição. ${ }^{62}$ Em agosto de 1828 surgiu no Rio de Janeiro o periódico O Analista ${ }^{63}$, com o qual o Farol travou intenso debate, fundado muito mais na troca de ofensas do que no enfrentamento de propostas políticas. Segundo o Farol, o Analista era "anticonstitucional, inimigo dos liberais e zelozo com Portugal", e suas matérias visavam denegrir a imagem da Câmara dos Deputados e ocultar os atos ilícitos do Ministério. Até fins de 1829, foram sucessivas as discussões sobre a atuação dos ministros e da Câmara dos Deputados. ${ }^{64}$

O terceiro e último momento de $O$ Farol Paulistano perdurou da segunda metade de 1830, especialmente após a morte do jornalista Libero Badaró, em novembro, até junho do ano seguinte, já no final da circulação do periódico. Concebida num primeiro momento como obra de "alguns poucos" liberais mais arrojados, a questão do "exaltamento" liberal foi aos poucos ganhando espaço, tornando-se umas das temáticas centrais do jornal. Pela primeira vez os opositores de $O$ Farol deixaram de ser exclusivamente representados por aqueles elementos afinados com o governo de D. Pedro, para advirem do próprio campo liberal, situação que se materializou no debate travado com jornais exaltados como A Voz Paulistana e o Observador Constitucional na fase pós-Abdicação.

Nas páginas de $O$ Farol, o debate conflagrado no seio dos liberais teve como pano de fundo três problemáticas basilares que se fortaleceram após a Abdicação: a reforma da Constituição, a 
federação e o republicanismo. Se em princípio qualquer uma delas foi peremptoriamente refutada pelo Farol, a pouco e pouco, devido ao combate incisivo protagonizado pelas folhas exaltadas e ao próprio curso da política dentro e fora do Legislativo, o jornal de Costa Carvalho mudou sua conduta e abriu espaço para discutir a plausibilidade ou não dessas questões, tornando-se nesse ponto um periódico de aspecto mais defensivo e de contra-ataque se comparado aos anos anteriores. Evidência disso está na "mudança de opinião" que o Farol assumiu ter operado sobre determinadas reformas propostas pelos exaltados para a Carta de 1824, especificamente aquelas que almejavam suprimir o poder de negação de sanção aos atos do Poder Legislativo pelo Moderador (artigo 179, cláusula $17^{\mathrm{a}}$ ), a atribuição do Supremo Tribunal de Justiça de conhecer os delitos dos vários funcionários públicos (artigo 164, cláusula 2a) e as eleições indiretas (artigo 90).

Cabe observar, por fim, que embora o Farol Paulistano seja representante do pensamento liberal paulista, as nuanças no posicionamento político desse periódico oferecem indícios para uma reflexão sobre a propalada "homogeneidade política"65 paulista na primeira metade do Oitocentos (HOLANDA, 1964). Se esta de fato existiu, é essencial que se busque compreender os motivos desse processo e de que forma a imprensa se inseriu nesse contexto. Por outro lado, a bibliografia mais recente tem enfatizado a maleabilidade dos princípios liberais durante a formação do Império, questionando o unitarismo dos chamados liberais "moderados", visto que os adeptos da "moderação" careciam de um programa definido como também de uma articulação mais ampla e coesa.

\section{Referências Bibliográficas}

BASILE, M.. Projetos de Brasil e construção nacional na imprensa fluminense (1831-1835). In: FERREIRA, T. M. B. da C.; MOREL, M.; NEVES, L. M. B. P.. (orgs.). História e Imprensa: representações culturais e práticas de poder. Rio de Janeiro: DP\&A/ Faperj, 2006, pp.60-93.

CASTRO, P. P. de. A 'experiência republicana', 1831-1840. In: HOLANDA, S. B. de (org.). História Geral da civilização brasileira. São Paulo: Difusão Européia do Livro: 1978, t. II, v. 2 , pp.315-352.

DOIN, J. E. de M. Dívida externa do Império. Organização e consolidação do Estado e início do processo de modernização dos instrumentos de exploração, 1824-1864. São Paulo, 1986.

Dissertação (Mestrado em História) - FFLCH,USP.

FREITAS, A. de. O primeiro centenário da fundação da imprensa paulista. Revista do Instituto Histórico e Geográfico de São Paulo, São Paulo, v.25, 1928.

GUIMARÃES, L. M. P. Liberalismo Moderado: postulados ideológicos e práticas políticas no período regencial (1831-1837). In: PEIXOTO, A. C.; GUIMARÃES, L. M. P.; PRADO, M. E. (orgs.). O liberalismo no Brasil Imperial: origens, conceitos e prática. Rio de Janeiro: Editora Revan, 2001. 
HOLANDA, S. B. de. São Paulo. In: HOLANDA, S. B. de. (org.). História Geral da civilização brasileira. São Paulo: Difusão Européia do Livro, 1964, t. II, v. 2, pp.415-472.

JACQUES, P.. O governo parlamentar e a crise brasileira. [Coleção Temas Brasileiros]. Brasília: Editora Universidade de Brasileira, 1982.

MONTEIRO, T. História do Império: o Primeiro Reinado. São Paulo: Itatiana/UDUSP, 1982.

MOREL, M.; BARROS, M. M. de. Palavra, imagem e poder: o surgimento da imprensa no Brasil do século XIX. Rio de Janeiro: DP \& A, 2003.

As transformações dos espaços públicos: imprensa, atores políticos e sociabilidade na cidade imperial (1820-1840). São Paulo: Hucitec, 2005.

RIBEIRO, G. S.. Causa nacional e cidadania: a participação popular e a autonomia na imprensa carioca no início dos anos 1830. In: FERREIRA, T. M. B. da C.; MOREL, M.; NEVES, L. M. B. P.. (orgs.). História e Imprensa: representações culturais e práticas de poder. Rio de Janeiro: DP\&A/ Faperj, 2006, pp. 113-141.

SILVA, W.. A imprensa e a pedagogia liberal na província de Minas Gerais (1825-1842). In: FERREIRA, T. M. B. da C.; MOREL, M.; NEVES, L. M. B. P.. (orgs.). História e Imprensa: representações culturais e práticas de poder. Rio de Janeiro: DP\&A/ Faperj, 2006, pp.37.59.

SISSON, S.A. Galeria dos brasileiros ilustres. Brasília: Senado Federal, 1999, $1^{\text {a }}$ edição: 1948, v.1, p.84; FREITAS, op. cit.; CONTIER, A.. Imprensa e ideologia em São Paulo, 1822-1842: matizes do vocabulário político e social. Petrópolis: Vozes, 1979.

SODRÉ, Nelson Werneck. A história da imprensa no Brasil. Rio de Janeiro: Imprensa Brasileira, 1966.

SOUSA, Otávio Tarquínio de. A vida de D. Pedro I. Rio de Janeiro: José Olympio Editora, 1957.

TAUNAY, A. de Escragnolle. História da cidade de São Paulo sob o Império: 1822-1831. São Paulo: Divisão do Arquivo Histórico, vol.4, 1956.

. História da cidade de São Paulo sob o Império: 1831-1842. São Paulo: Divisão do Arquivo Histórico, vol.5, 1961.

. A Câmara dos deputados sob o Império. São Paulo: Imprensa Oficial do Estado de São

Paulo, 1950.

TOLEDO, L. de. Imprensa Paulista. Revista do Instituto Histórico e Geográfico de São Paulo. São Paulo: Typografia do Diário Oficial, v.03, 1898, pp.303-521;

WERNET, Augustin. Sociedades políticas (1831-32). São Paulo: Cultrix, 1978.

\section{NOTAS}

\footnotetext{
${ }^{1}$ Nas demais províncias do Império, a imprensa demorou mais a se estabelecer, tal como em Goiás (1830), Santa Catarina (1831), Alagoas (1831), Sergipe (1832), Rio Grande do Norte (1832), Espírito Santo (1840), Paraná (1853) e Amazonas (1854).
} 
${ }^{2}$ Antonio Mariano de Azevedo Marques (1797-1844), o Mestrinho, era natural de São Paulo. Filho de Manoel Eufrásio de Azevedo Marques, tornou-se conhecedor de latim já em sua juventude, fazendo com que desse aulas para os integrantes do coral da Catedral da Sé, quando recebeu o apelido de Mestrinho. Em 1822, foi nomeado professor da cadeira pública de Latim e Retórica da cidade de São Paulo. Em 1828, quando da fundação do Curso Jurídico de São Paulo, ocupou a cadeira de Latim e Retórica anexa ao Curso Jurídico, cargo que desempenhou até 1835. Entre as décadas de 1820 e 1830, ocupou os cargos de escrivão da irmandade de Santa Casa de Misericórdia (1823-1825), juiz de paz, vereador, membro dos Conselhos da Presidência e Geral, vice-presidente (1837) e secretário da presidência (1839-1842), todos pela Província de São Paulo. No fim da vida, ainda ocupou o cargo de auxiliar de gabinete do Visconde de Macaé, no Rio de Janeiro.

${ }^{3}$ SODRÉ, op. cit., pp.100-101. Por ser manuscrito, o Paulista possuía um sistema singular de funcionamento que foi explicitado em seu primeiro número. Werneck Sodré transcreveu-o: "Como, desgraçadamente, não tem sido possível a província de São Paulo obter um prelo para se comunicarem e disseminarem as ideias úteis e as luzes tão necessárias a um país livre, para dirigir a opinião pública, cortando pela raiz os boatos que os malévolos não cessam de espalhar para conseguir seus fins ocultos, é mister lançar mão do único meio que nos resta. Deverá pois ser suprimida a falta de tipografia pelo uso de amanuenses, que serão pagos por uma sociedade patriótica, e aos quais incumbe escrever o número de folhas, que devem ser repartidas pelos subscritores no dia determinado para a sua publicação".

${ }^{4}$ José da Costa Carvalho (1796-1860), Barão, Visconde e depois Marquês de Monte Alegre, era natural da Freguesia da Nossa Senhora da Penha, situada nos arredores de Salvador. Filho de pai homônimo e de Ignez Maria Piedade Costa, estudou Leis na Universidade de Coimbra, onde se formou em 1819. De volta ao Brasil, iniciou sua carreira pública pela magistratura, ocupando os cargos de juiz de fora e ouvidor da cidade de São Paulo entre 1821 e 1822, período em que se casou com Genebra de Barros Leite, viúva do Brigadeiro Luis Antonio de Sousa Queiróz. Sua carreira política iniciou-se quando foi eleito ao cargo de deputado pela Bahia para a Assembleia Constituinte de 1823. Ao longo do Primeiro Reinado, foi deputado pela Bahia nas duas primeiras Legislaturas. Durante esse período, foi presidente da Câmara dos Deputados (de 5 de maio a 3 de julho de 1828; de 4 de maio a 3 de julho de 1830; de 3 de agosto de 1830 a 4 de maio de 1831); Vice-Presidente da Câmara dos Deputados (de 4 de maio de 1827 a 5 de maio de 1828); e Primeiro Suplente da Mesa Diretora (de 2 de agosto de 1828 a 4 de maio de 1829). Ainda durante o Primeiro Reinado, Costa Carvalho foi membro regular dos Conselhos da Presidência e Geral de São Paulo. Com a Abdicação, tornou-se membro da Regência Trina Permanente, em 17 de junho de 1831. Ainda foi deputado pela Província de São Paulo na $4^{\mathrm{a}}$ Legislatura (1838-1841), com posse a 19 de maio de 1838; senador pela Província de Sergipe (1839-1860), com posse em 4 de maio de 1839; Presidente da Província de São Paulo (de 20 de janeiro a 16 de agosto de 1842); Presidente do Senado (1842-1843); Conselheiro de Estado (a partir de 1842); Ministro e Secretário de Estado dos Negócios do Império ( $10^{\circ}$ Gabinete do $2^{\circ}$ Reinado, entre de 29 de setembro de 1848 e 11 de maio de 1852$)$; e Presidente do Conselho de Ministros do $10^{\circ}$ Gabinete a partir de 8 de outubro de 1849. Fora da política, foi sócio do Instituto Histórico e Geográfico Brasileiro; fundador da Sociedade de Estatística do Brasil e da Associação Central de Colonização do Rio de Janeiro; membro honorário da Sociedade Auxiliadora da Indústria Nacional, da Academia Imperial das Belas-Artes e de outras associações de letras e ciências. Foi elevado a Barão (1841), Visconde com grandeza (1843) e Marquês de Monte Alegre (1854).

${ }^{5}$ É provável que o $\mathrm{n}^{\circ} 504$ (30/06/1831) tenha sido o último de o Farol Paulistano, uma vez que a bibliografia e arquivos consultados não fazem menção a números posteriores.

${ }^{6}$ O Farol Paulistano, $\mathrm{n}^{\mathrm{o}} 12,25 / 04 / 1827$. Atualmente a rua S. José recebe o nome de Líbero Badaró. A partir do no 126 (02/071828) a tipografia passou a se chamar Typographia do Farol Paulistano.

${ }^{7}$ A partir do no 241 (26/08/1829), o Farol mudou o aspecto de sua diagramação, tornando-se melhor impresso e mais legível.

${ }^{8}$ O Farol Paulistano, $\mathrm{n}^{\circ} 221,06 / 06 / 1829$.

${ }^{9}$ O Farol Paulistano, $\mathrm{n}^{\mathrm{o}} 12,1827$.

${ }^{10} \mathrm{Cf}$. indica o $\mathrm{n}^{\circ} 20$ do Farol Paulistano, este passou a ser publicado duas vezes por semana, às quartas e aos sábados.

${ }^{11}$ O Farol Paulistano, $\mathrm{n}^{\circ} 247,16 / 09 / 1829$.

${ }^{12}$ O Farol Paulistano, $\mathrm{n}^{\circ} 12,25 / 04 / 1827$.

${ }^{13}$ O Farol Paulistano, $\mathrm{n}^{\circ} 39,22 / 08 / 1827$.

${ }^{14} \mathrm{O}$ Farol Paulistano, $\mathrm{n}^{\mathrm{o}} 331,17 / 04 / 1830$. Em linhas gerais, o artigo criticava a atitude pouco enérgica assumida pela Aurora Fluminense - periódico-chave na construção do discurso de o Farol e recorrentemente elogiado por esse quando de sua absolvição frente às acusações do Conselheiro Francisco Gomes da Silva sobre o abuso da liberdade de imprensa pela folha fluminense.

${ }^{15}$ O Farol Paulistano, $\mathrm{n}^{\circ}$ 481, 30/04/1831.

${ }^{16}$ Embora eleito Conselheiro, José da Costa Carvalho participou de apenas três sessões da Segunda Reunião do Conselho da Presidência da Província de São Paulo, transcorrida entre 1830-1833. Cf. Atas do Conselho da Presidência da Província de São Paulo (1829-1832). In: Boletim. São Paulo: Arquivo do Estado de São Paulo, 1961, v.15, sessões de 18/01/1831, 21/01/1831 e 26/03/1831, pp. 138-139.

${ }^{16}$ O Farol Paulistano, $\mathrm{n}^{\circ}$ 481, 16/11/1830.

${ }^{17}$ Antonio Mariano de Azevedo Marques ocupou o cargo de Suplente do Conselho da Presidência da Província de São Paulo entre 30/06/1830 e 20/10/1831. Cf. ACP, v.15, pp.50 e 191.

${ }^{18}$ O Farol Paulistano, $\mathrm{n}^{\circ}$ 481, 16/11/1830. 
${ }^{19}$ Nicolau Pereira de Campos Vergueiro (1778-1859) era natural de Bragança, Portugal. Após formar-se em Direito pela Universidade de Coimbra, em 1801, erradicou-se na América, mais precisamente em São Paulo, onde exerceu a advocacia, além de ser proprietário e comerciante. Como político, participou do Governo Provisório de São Paulo, sendo eleito deputado pela mesma Província para as Cortes de Lisboa (1821) e, posteriormente, para a Assembléia Constituinte (1823). Eleito deputado por São Paulo para a $1^{\text {a }}$ Legislatura do Império, foi substituído em 1829 pelo Desembargador João de Medeiros Gomes, uma vez que havia sido eleito senador por Minas Gerais. Ainda durante o Primeiro Reinado, foi eleito Suplente para $1^{\mathrm{a}}$ Reunião do Conselho da Presidência e Conselheiro para a $2^{\mathrm{a}}$, ambos pela Província de São Paulo. Após a Abdicação, foi membro da Regência Trina Provisória (1831) e ministro diversas vezes entre 1832-33 e 1847, e diretor do Curso Jurídico de São Paulo, entre 1837-1842.

${ }^{20}$ Denominação utilizada por alguns periódicos, tais como O Observador Constitucional e A Voz Paulistana, para discriminar o artigo principal dentro da folha. Arnaldo Contier, utilizou o termo com o mesmo sentido, também empregado aqui. Cf. CONTIER, op. cit.

${ }^{21}$ Exemplos desses artigos são "Da monarquia constitucional e representativa" (O Farol Paulistano, n 02, 1827) e "Da Tyrannia" (O Farol Paulistano, nº 89, 16/02/1828).

${ }^{22}$ Ver O Farol Paulistano, n's $1(07 / 02 / 1827)$ e $247(16 / 09 / 1829)$.

${ }^{23}$ Ver, por exemplo, O Farol Paulistano, n's 37 (16/08/1827) e 155 (11/10/1828).

${ }^{24}$ Isso não impedia, todavia, que o periódico fosse levado a julgamento por publicar uma correspondência supostamente caluniosa. Em 1827, a Astréa foi julgada e absolvida por conta de uma correspondência que havia levantado suspeitas sobre um promotor do Rio de Janeiro, cf. O Farol Paulistano, no 74, 22/12/1827.

${ }^{25}$ O Farol Paulistano, $\mathrm{n}^{\circ} 12,25 / 04 / 1827$.

${ }^{26}$ O Farol Paulistano, no $202,01 / 04 / 1829$.

${ }^{27}$ Rafael Tobias de Aguiar (1794-1857) era natural de Sorocaba e filho de Antonio Francisco de Aguiar e D. Gertrudes Eufrosina Aires. Em 1821, foi nomeado eleitor pela Comarca de Itu para as Cortes de Lisboa, não conseguindo, todavia, eleger-se deputado. Pela Província de São Paulo, foi eleito deputado pela $2^{\mathrm{a}}$ e $3^{\mathrm{a}}$ Legislaturas, Conselheiro do Conselho da Presidência e do Conselho Geral na $1^{\text {a }}$ e $2^{\text {a }}$ Reuniões. Foi presidente da Província de São Paulo em nas seguintes ocasiões: entre 17 de novembro de 1831 e 27 de maio de 1834; de 14 de setembro de 1834 até 10 de maio de 1835 ; e de 6 de agosto de 1840 até 14 de julho de 1841.

${ }^{28}$ José Arouche de Toledo Rendon (1756-1834) era natural de São Paulo e formado em Direito pela Universidade de Coimbra em 1779. De volta à América Portuguesa, dedicou-se à advocacia e iniciou sua carreira militar em 1789, em São Paulo. Em 1817, organizou os corpos de milícia destinados às campanhas do sul. Em 1822, foi promovido a marechal de campo, ano em que também ocupou o cargo de Governador das Armas de São Paulo, Província pela qual foi eleito deputado da Assembleia Constituinte de 1823. Foi ainda provedor da Santa Casa de Misericórdia, diretor do Curso Jurídico de São Paulo, entre 1828-1833, e Suplente do Conselho da Presidência de São Paulo entre 1827 e 1830. Eleito deputado para a $1^{a}$ Legislatura do Império, não tomou assento, sendo substituído pelo brigadeiro Ignácio José Vicente da Fonseca.

${ }^{29}$ Francisco de Paula Sousa e Melo (1791-1851) era natural de Itu. Filho de Antônio José de Sousa e D. Gertrudes Solidônia de Cerqueira, iniciou sua carreira política na Câmara Municipal de Itu. Eleito deputado pela Província de São Paulo para as Cortes de Lisboa, em 1821, não embarcou para Portugal por alegar doença. Pela Província de São Paulo, foi eleito deputado para a Assembleia Constituinte (1823) e a $1^{\mathrm{a}}, 2^{\mathrm{a}}$ e $3^{\mathrm{a}}$ Legislaturas do Império. Foi ainda Conselheiro do Conselho Geral na $2^{a}$ e $3^{a}$ Reuniões, ambas por São Paulo. Após a Abdicação, foi senador (1833), ministro do Império (1847) e da Fazenda (1848).

30 Ver, respectivamente, $O$ Farol Paulistano, $n^{\circ}$ s 70 (07/12/1827), 71 (12/12/1827), 249 (22/09/1829) e 300 $(25 / 01 / 1830)$.

${ }^{31}$ O Observador Constitucional, $\mathrm{n}^{\circ} 35,01 / 03 / 1830$.

${ }^{32}$ Para a relação completa dos excertos e autores inseridos no Farol Paulistano e no Observador Constitucional, ver Anexos 2 e 5 .

${ }^{33}$ A relação dos títulos listados no inventário de Genebra de Barros, quase todos em francês e que totalizavam 326 volumes, encontra-se publicada em ARAÚJO, M. L. V.. Os caminhos da riqueza dos paulistanos na primeira metade do oitocentos. São Paulo: Hucitec, 2006, pp.171-178. Sobre o fato de a biblioteca ser uma das mais imponentes da cidade, ver OLIVEIRA, A. J. B. de. Memórias de um Magistrado do Império. São Paulo: Companhia editora nacional. Série Pedagógica Brasileira: Brasiliana, v.231, 1943.

${ }^{34}$ CONTIER, op. cit.

${ }^{35}$ Sobre os problemas intrínsecos ao ato de traduzir, ver ECO, U.. Os Limites da Interpretação. São Paulo: Perspectiva, 2000; VIEIRA, E. R. P. (org.). Teorizando e contextualizando a Tradução. Belo Horizonte: UFMG, 1996; e BERMAN, A.. A prova do estrangeiro: cultura e tradução na Alemanha romântica. Bauru/ SP: EDUSC, 2002.

${ }^{36}$ O Farol Paulistano, no $165,19 / 11 / 1828$.

${ }^{37}$ O Farol Paulistano, no 149, 20/09/1828. São muitas as controvérsias em torno de Francisco Gomes da Silva e João da Rocha Pinto, tidos os integrantes do chamado "gabinete secreto" do imperador no final do Primeiro Reinado. Amigos próximos de D. Pedro e articuladores da vida íntima do monarca, ambos ganharam maior notoriedade após a morte de D. João VI, em 1826, quando a questão sucessória do trono português inscreveu-se como elemento importante da política externa do governo de D. Pedro, a despeito das críticas sofridas especialmente da oposição liberal. Gomes da Silva, sobretudo, tornou-se homem de confiança do monarca no tratamento do problema, que se 
agravou com a usurpação da coroa portuguesa por D. Miguel, em fevereiro de 1828. A falta de clareza a respeito das efetivas atribuições conferidas aos dois secretários e a ambiguidade do monarca sobre o assunto gerou insatisfação por parte do próprio ministério - naquela época formado pelos marqueses de Barbacena, Caravelas, Rio Pardo e Paranaguá, por Miguel Calmon du Pin e pelo Visconde de Alcântara -, que negociou com D. Pedro a saída de ambos do Brasil, em abril de 1830. Sobre a atuação política de Rocha Pinto e Gomes da Silva, ver SOUSA, Otávio Tarquínio de. A vida de D. Pedro I. Rio de Janeiro: José Olympio Editora, 1957, v.3, capítulo XXIV, e MONTEIRO, T. História do Império: o Primeiro Reinado. São Paulo: Itatiana/UDUSP, 1982.

${ }^{38}$ Rodrigo Antonio Monteiro de Barros (?-1844) era natural de Minas Gerais. Filho de Lucas Antonio Monteiro de Barros, o Visconde de Congonhas do Campo, tornou-se bacharel em Direito pela Universidade de Coimbra, em 1827 , quando foi nomeado juiz de fora da cidade de São Paulo. Casou-se, em 1828, com Maria Marcolina Prado, ao mesmo tempo meia-irmã e prima de Antonio da Silva Prado, o Barão de Iguape. Foi deputado por São Paulo na $2^{\mathrm{a}}$, $3^{\mathrm{a}}$ e $4^{\mathrm{a}}$ Legislaturas, e desembargador da Relação de Pernambuco em 1842.

39 O Farol Paulistano, n ${ }^{\circ}$ 75, 29/12/1827. Para a relação de todas as obras vendidas na Tipografia do Farol Paulistano, ver Anexo 3.

${ }^{40}$ O Farol Paulistano, nos 75 (29/12/1827) e 131 (19/07/1828).

${ }^{41}$ O Farol Paulistano, $\mathrm{n}^{\circ} 250,26 / 09 / 1829$. Ver também no 227, 08/07/1829.

${ }^{42}$ O Farol Paulistano, no 366, 20/07/1830.

${ }^{43}$ O Observador Constitucional, $\mathrm{n}^{\circ} 68,16 / 07 / 1830$.

${ }^{44}$ O Observador Constitucional, $\mathrm{n}^{\circ} 31,12 / 02 / 1830$.

${ }^{45}$ O Farol Paulistano, $\mathrm{n}^{\circ}$ 56, 20/10/1827.

${ }^{46}$ As diretrizes básicas da Sociedade de Guaratinguetá foram enviadas pelos seus integrantes ao Farol Paulistano por meio de um artigo comunicado que veio a público no $\mathrm{n}^{\circ} 313$, em 04/03/1830.

${ }^{47}$ O Farol Paulistano, $\mathrm{n}^{\circ} 416,16 / 11 / 1830$.

${ }^{48}$ Cf. artigo 61 da Lei de $1^{\circ}$ de outubro de 1828 - Dá nova fórma as Câmaras Municipaes, marca sua attribuições, e o processo para a sua eleição, e dos Juizes de Paz. In: Coleção das Leis do Império do Brasil de 1828. Rio de Janeiro: Tipografia Nacional, 1878, pp.74-88.

${ }^{49}$ Registro Geral da Câmara da cidade de São Paulo, 1832. São Paulo: Publicação Oficial do Arquivo Municipal de São Paulo, 1936, v. XXII, pp.256 e 261-262.

${ }^{50}$ O Astro de Minas, $\mathrm{n}^{\circ} 26,17 / 01 / 1828$.

${ }^{51}$ O Astro de Minas, $\mathrm{n}^{\circ}$ 304, 29/10/1829.

${ }^{52}$ Ver, por exemplo, as correspondências publicadas no n ${ }^{\circ} 243$ de $O$ Farol Paulistano, em 02/09/1829.

${ }^{53}$ O Farol Paulistano, $\mathrm{n}^{\mathrm{o}} 311,23 / 02 / 1830$.

${ }^{54}$ A Aurora Fluminense, $\mathrm{n}^{\circ}$ 563, 30/11/1831.

${ }^{55}$ Ibid., p.65.

${ }^{56}$ O Justiceiro, $\mathrm{n}^{\mathrm{o}} 01,07 / 11 / 1834$.

${ }^{57}$ O Farol Paulistano, $\mathrm{n}^{\circ}$ 1, 07/02/1827. Grifo nosso.

${ }^{58}$ A tendência governista da Gazeta do Brasil foi assinalada, também, por Otávio Tarquínio de Sousa, Affonso Taunay, Nelson Werneck Sodré e Marco Morel, conforme obras já citadas.

${ }^{59}$ O Farol Paulistano, no $20,16 / 06 / 1827$.

60 Em outubro de 1829, o Farol Paulistano foi "levado a juízo" por ter sido acusado de abuso de liberdade de imprensa por um artigo publicado no $\mathrm{n}^{\circ} 211$ que colocava em dúvida a honestidade do então Ministro da Fazenda Miguel Calmon. O jornal foi absolvido em fevereiro do ano seguinte. Para o acompanhamento da questão, ver os $\mathrm{n}^{\circ} \mathrm{s} 211$ (06/05/1829), 257 (13/10/1829) e 313 (27/02/1830).

${ }^{61}$ Segundo o redator de $O$ Farol Paulistano, o Censor Brasileiro tinha alguma relação com o ministro Clemente Pereira, uma vez que falas inteiras desse político eram constantemente inseridas naquele periódico, cf. $O$ Farol Paulistano, $\mathrm{n}^{\circ}$ 125, 28/06/1828. Não se pode afirmar, contudo, que tal relação de fato tenha ocorrido.

${ }^{62}$ Ver O Farol Paulistano, n’ 112 (14/05/1828), 113 (17/05/1828), 125 (28/06/1828) e 129 (12/07/1828).

${ }^{63}$ Segundo o Farol Paulistano, o Analista era de propriedade do então ministro da Fazenda Miguel Calmon du Pin e Almeida, ou por ele protegido. A despeito de seu alinhamento com o Governo, não foram encontrados elementos que comprovem a afirmação de $O$ Farol.

${ }^{64}$ Ver O Farol Paulistano, n’s 142 (27/08/1828), 150 (24/09/1828), 158 (22/10/1828), 195, (07/03/1829), 201 $(28 / 03 / 1828$

65 Para Sérgio Buarque de Holanda, a política de São Paulo ao longo do Primeiro Reinado teria como característica uma feição homogênea, uma vez que as disputas políticas decorriam muito mais de desavenças: "seja com for, a Província de S. Paulo guardará durante todo o Primeiro Reinado e parte da Regência uma fisionomia política apreciavelmente unitária. Podiam sobreviver as diferenças pessoais, que mal perturbariam a coerência fundamental do pensamento político. Politicamente a maré liberal conhece poucas cambiantes e não parece sofrer refluxo [...] Mesmo os antigos 'bernardistas' deixam-se contaminar pela pressão geral: não falta, entre eles, quem chegue a dizer-se republicano. José da Costa Carvalho funda, em 1827, uma folha de oposição, o primeiro jornal impresso em S.Paulo, e torna-se protetor de Badaró [...] Em verdade esse liberalismo dos paulistas natos ou adotivos, fruto de um espírito de independência que impressionava vivamente Armitage e que, segundo depoimento de Francisco Gomes da Silva, o valido do imperador, não tem igual em todo o Brasil, continuará a ser força ativa na política nacional”, cf. HOLANDA, 
op. cit., pp.458-459. Ainda segundo o autor, a consolidação dos ideais liberais na política paulista foi resultado de um processo misto, marcado pelo declínio dos ideais do Antigo Regime, e por uma conduta político-administrativa que foi se adequando às mudanças estruturais que a economia paulista vinha sofrendo desde meados do século XVIII. Para ele a vila de Itu serve como exemplo paradigmático desse processo, na medida em que foi pioneira da grande lavoura comercial, do liberalismo e da emancipação nacional na província. Assim, no seu entender, a afirmação do liberalismo em São Paulo não foi resultado da mera importação de pressupostos políticos europeus desconexos da realidade da província, mas de uma lenta alteração na mentalidade dos setores econômicos que, para dar tangibilidade a seus empreendimentos cada vez mais lucrativos, encontraram nas teorias liberais um instrumento político essencial.

Artigo recebido em 08/2009. Aprovado em 04/2010. 